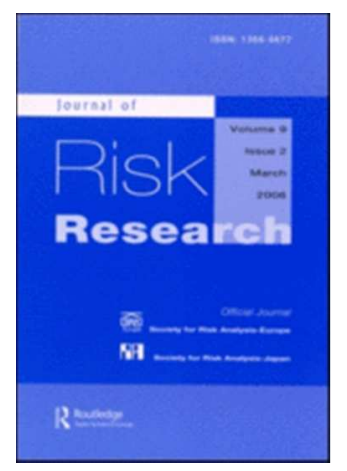

\title{
How Do Incentives Influence Local Public Support for the Siting of Shale Gas Projects in China?
}

\begin{tabular}{|r|l|}
\hline Journal: & Journal of Risk Research \\
\hline Manuscript ID & RJRR-2018-0019.R2 \\
\hline Manuscript Type: & Original Article \\
\hline Keywords: & $\begin{array}{l}\text { shale gas, attitudes toward energy development, household compensation, } \\
\text { community reinvestment, experiment }\end{array}$ \\
\hline \multicolumn{2}{|c}{} \\
\hline
\end{tabular}

SCHOLARONE

Manuscripts 


\title{
How Do Incentives Influence Local Public Support for the Siting of Shale Gas Projects in China?
}

\begin{abstract}
In 2016, China became the third largest producer of shale gas in the world. The Chinese central government has been supporting shale gas development since 2011. There are hopes that shale gas development, along with major efforts in renewable energy systems, can bring a fundamental change in the nation's current coal-dependent energy system.
\end{abstract}

Numerous challenges have slowed implementation including resistance to development of the industry by local residents living near shale gas sites. A significant body of research has examined the effectiveness of incentives in changing risk perceptions and attitudes toward the siting of industrial projects in the Western context. The present research identifies whether governmental incentives increase the extent of local support for shale gas projects in the Chinese context. Specifically, this paper strives to study two types of incentives: direct compensation to households bearing the potential negative impacts of shale gas projects and, household compensation accompanied by allocation of a portion of the shale tax revenues to local communities where the development occurs.

An online survey with an embedded experiment was designed and conducted in August 2016 in five Chinese provinces where there are current or future shale gas projects. The experiment shows that household compensation alone or in combination with community reinvestment significantly increases local support of shale gas projects. Further, we found that the respondents most likely to be supportive after the experimental treatments are those who are young, more highly educated, have higher income, and perceive themselves as living close to a project. This research sheds light on how incentives might help contribute to resolution of siting controversies or prevent the onset of such controversies.

Key words: shale gas; attitudes toward energy development; household compensation; community reinvestment; experiment. 


\section{Introduction}

The rapid growth in energy demand, coupled with concerns about local environmental quality, energy security and climate change have led China to develop its shale gas resources. China has the largest technologically recoverable shale gas resources in the world, but development is at an earlier stage compared to production in the United States. In the past decade, production has increased at an exponential rate, from zero in 2009 to 0.1 billion cubic meters (bcm) in 2012, $1.247 \mathrm{bcm}$ in 2014 and then $4.471 \mathrm{bcm}$ in 2015. In 2016 shale gas production increased 76.3 percent over the 2015 level to a record $7.882 \mathrm{bcm}$, elevating China to the position of third largest shale gas producer in the world, after the US and Canada (Ministry of Land and Resources of the People's Republic of China 2017). At this time, exploration and extraction activities are mainly located in the Sichuan Basin of China (Hu et al. 2016).

The Chinese central government has strongly supported shale gas exploration and development. Fiscal incentives and exemptions from taxes have been available since 2011. In 2018, the central government cut the resource tax on shale gas production by 30 percent. Shale gas development is a priority because it is perceived as helping China's energy system transform from dependence on coal to a cleaner energy system.

Prior studies have focused on the geological and technological aspects of shale gas development (Ding et al. 2016; Guo et al. 2016; Liu et al. 2015; Pi et al. 2015; Wan, Huang, and Craig 2014). Little systematic research has been done regarding public opinion on shale gas development in China. In addition to these academic investigations, there has been limited reporting in the media of the social impacts that new development may pose to inhabitants living near development areas. Some local news stories reveal the sentiments of people toward development, including one piece that covers local opposition in Sichuan that led to a temporary 
halt to operations. However, there are no rigorous scientific studies in the literature that reveal attitudes toward shale gas among the general population in China. This paper begins to fill this gap in the social research by studying the breadth and basis of local residents' attitudes toward shale gas development in China.

Specifically, this paper examines whether incentives, including household compensation and community reinvestment, increase local residents' support for shale gas development. Local attitudes toward energy infrastructure have been studied previously in both the siting literature and the risk analysis literature. The "Not in my backyard" (NIMBY) syndrome was first proposed to describe opposition to locally unwelcome facilities that are generally favored at a societal level. The NIMBY literature has produced somewhat simplistic explanations of the phenomena of local opposition (Rabe 1991; Kraft and Clary 1991; Kunreuther, LinneroothBayer, and Fitzgerald 1996; Short and Rosa 2004; Freudenburg 2004; Boholm and Lofstedt 2013; Alcorn, Rupp, and Graham 2017). Public irrationality, annoyance, and self-interest explanations for the NIMBY syndrome lack empirical evidence (Freudenburg and Pastor 1992). Attitudes appear to be related to the broader siting system, which can create or exacerbate opposition, thus stimulating interest in studies of the decision making processes concerning unwelcome facilities (Aaen, Kerndrup, and Lyhne 2016; Freudenburg and Pastor 1992). This paper contributes to this knowledge base about the motivation for local opposition by studying the effect of providing financial incentives to local residents and how it affects their attitudes toward a hypothetical shale gas project. Using an experimental method, we observe how the nearby public reacts to incentives, and how residents balance the perceived costs and benefits of nearby shale gas projects. If incentives increase local support for shale gas development, the implication is that local opposition is not rooted in irrationality or ignorance. As incentives provided to households 
affect attitudes, it would seem that self-interest considerations are an important piece of the puzzle. A strength of the experimental method is that it isolates the effect of incentives and avoids factors that might confound the effect of government-sponsored incentives on local attitudes towards potentially unwelcome energy facilities. 
natural gas currently plays a small role in China's energy mix, the central government plans to increase natural gas consumption from $5.9 \%$ of total energy consumption today to 10 percent by 2020 and 15 percent by 2030 (Ministry of Land and Resources of the People's Republic of China 2017). Shale gas development is currently relatively uncontested in China compared to the situation in Europe and some US states (e.g., New York), where opponents to development have persuaded some governments to enact moratoria over industry objections.

Several factors contributed to the Chinese central government's decision to develop shale gas resources. China was aware of the technological innovation occurring in North America and saw this innovation as a strategy to address the country's long-standing desire to reduce the country's dependence on energy supplies from foreign countries ( $\mathrm{Hu}$ and $\mathrm{Xu}$ 2013). In addition, the central government regards shale gas as a clean and efficient energy source. Thus, shale gas is, a key part of the national strategy to reduce the country's heavy dependence on coal, thereby mitigating both the local and global environmental damages that result from using coal (State Council of the People' Republic of China 2014). Shale gas development is also seen as a promising tool of local and national economic development, as explained in The $13^{\text {th }}$ Five-Year Plan for Shale Gas (National Energy Administration 2016).

The central government's aspirations for shale gas development have been backed by significant government incentives for production activity. A fiscal development subsidy of 0.3 yuan was made available from 2016 to 2018, declining to 0.2 yuan from 2019 to 2020 (Ministry of Finance and National Energy Administration 2015). Exemptions were also authorized from two types of government fees and tariffs typically applied to natural resource activities, including tariffs on sales of equipment imported for shale gas development projects (National Energy Administration 2013). The central government also spent over 13 billion yuan (1.9 billion US 
dollars) in 2015 and an additional 8.79 billion yuan (1.3 billion US dollars) in 2016 prospecting for shale gas (Ministry of Land and Resources of the People's Republic of China 2017).

While the central government has strongly supported shale gas development, a number of challenges have slowed development. The biggest technical challenge is the complicated geological conditions that exist in China. This challenge can be partially offset by drilling deeper and, by utilizing more advanced technologies than have often been used in North America (Pi et al. 2015; Liu et al. 2015; Zhao and Yang 2015). As a result, China's shale gas industry will require more technological innovation to lower the costs of drilling (Tian et al. 2014). Other obstacles to development include a shortage of water, which is a necessary component in the development process, particularly for hydraulic fracturing of wells; insufficient infrastructure (e.g., pipelines) to deliver shale gas to markets; a less competitive energy market, which attenuates incentives for innovation; and government-regulated natural gas pricing, which curtails the profitability of development (Hu and Xu 2013; Zhao and Yang 2015; Wan, Huang, and Craig 2014; Graham, Mitchell, and Rupp 2013).

Prior literature on the challenges of shale gas development in China has focused on the technical and economic aspects and overlooked potential societal factors, including attitudes of local residents toward shale gas development. The activities associated with shale gas development can be regarded as a potential NIMBY "facility". Two of the areas in China with extensive shale gas resources are the Sichuan Basin and the Yangtze Platform. In contrast to some of the rural environments in the US (e.g., North Dakota and north central Pennsylvania), the Sichuan and Yangtze locations are densely populated and extensively farmed. Many drilling sites are located close to residential areas. For example, drilling sites in Maoba, a village in Sichuan, are within 360 feet of residential homes. Local residents complain about noise pollution, 
dust and other environmental concerns. After Shell started preliminary exploration in the Sichuan region in May 2010, the company lost 535 days of work across 19 wells due to "spontaneous village-based blockades" or requests from the local government to halt operations (Spegele and Scheck 2013). In addition, unlike landowners in the US, Chinese residents do not financially benefit from leasing-related signing bonuses or royalty payments because the central government owns the land and minerals that lie underneath farms, residential homes and apartments. Nor are local governments in a good position to provide incentives or compensation to local residents because there is a waiver of the natural resources tax on shale gas development, a tax that might otherwise raise revenue to support local compensation and incentives. In an unusual arrangement, State-owned Sinopec (China Petroleum and Chemical Corporation) did give a $1 \%$ stake in its Fuling unit to local government investment firms to enhance community development, and this provision may have provided local officials with stronger incentives to support Sinopec's shale gas development (Spegele 2016). Nonetheless, such local incentives are not standard practice in China.

However, as stated earlier, even without local compensation and incentives, shale gas development has been popularized as positive for the public because it produces clean energy that will contribute to China's green energy transformation. It is also seen as contributing to economic development and energy security.

Based on the North American and European experiences, public opinion (including attitudes toward positive and negative impacts) plays an important role in shale gas development (Graham, Rupp, and Schenk 2015). While local opinion influences the Chinese government in different ways than are typical of Western democracies, where the general public can directly influence policy making through voting, the Chinese government is known to be highly sensitive 
to public opinion, at least in some policy situations (see Zhong and Mol (2008) and Yang and Calhoun (2007)). The Chinese public makes use of the internet, engages in networking, and self organizes protests that may include over 100,000 residents (e.g., an anti-pollution petition in Baoding, Hebei). Such protests resulted in the resignation of the director of the Environmental Protection Agency. Indirect effects of public opinion on public policy in China through the media have been demonstrated as well (Luo 2014).

In contrast to the controversies about shale gas development in some regions of the US that have led to moratoria (e.g., the State of New York), the coverage of shale gas in official Chinese media and the mass media is typically positive and supportive. For example, Renmin ribao (People's Daily), one of the most influential official newspapers in China, published 372 articles that mentioned shale gas development in the text (keyword "shale gas") from 2010 to 2017. Fifty-one of the 372 articles contain "shale gas" in the title and a majority of them (41 of 51) mainly discussed environmental, economic, and/or energy independence benefits of shale gas development. When we searched "shale gas" in sina weibo (Chinese twitter), the most popular micro-blogging website in China, we found 603 tweets in total from October 2013 (the earliest record in sina weibo) to 2018. Most tweets were reposted from verified users (governmental users, scholars, industries, non-governmental organizations) and a majority of tweets indicated support for Chinese shale gas development.

The discussion about shale gas development in both traditional and social media is not as intensive and controversial as the US. One reason might be that shale gas drilling activities are happening only in less developed areas in Sichuan and Chongqing and have not yet generated wide attention by the general public. As a side note, we did find fourteen tweets that were concerned about the potential negative impacts brought by gas extraction. One tweet from a 
resident from Yongrong, Chongqing, complained about a drinking water contamination issue due to nearby drilling activity.

There are no publicly available representative public opinion surveys on shale gas development in China to our knowledge. We found one small qualitative study that involved interviews with 17 villagers from Sichuan and Chongqing where shale gas drilling is actively conducted (Sher 2016). Villagers had little awareness of the process of shale gas development. The most frequently discussed environmental impacts were water pollution (residents who lived within $100 \mathrm{~m}$ mentioned "black water" in their water well), water shortage, air pollution and noise pollution. In addition, those who leased land for shale gas development mentioned soil pollution because the top fertilized soil was damaged when returned. However, interviewees did not think that it was the shale gas development that caused water pollution and/or water shortage but rather a natural disaster. They also believed that the local government had responded promptly and that the water problem was not a major concern. On the positive impact side, interviewees pointed out a few economic benefits that they had experienced. For example, those who leased land had a significant income increase due to receiving lease payments (about $\$ 600$ per acre of land annually). Interviewees living in Jiaoshi, Chongqing, reported more economic benefits due to the larger scale of development and more job opportunities in restaurants and hotels compared with interviewees living in Xinchang, Sichuan is a region where the development is on a smaller scale and at an early stage. All interviewees mentioned improvement in local infrastructure, e.g. roads. The author concluded that while interviewees cited both environmental and economic impacts of shale gas development, the villagers were less concerned about the environmental impacts since they usually rely on the government to get information and these impacts are not widely discussed by the government. 
While large-scale scientific public opinion studies of shale gas development in China appear to be virtually non-existent, we found plenty of research on local acceptance of other energy facilities. Local opposition to siting energy facilities has become a pressing social issue in China (e.g. local protests against a nuclear waste reprocessing facility siting in Lianyungang (Hioe 2016), street protests against a paraxylene production facility siting in Jiangmen and Shanghai (Ruwitch and Stanway 2012), and street protests against a petrochemical plant in Kunming (Duggan 2013)). Scholars have proposed a variety of ways to solve the conflicts, mostly focusing on institutional approaches (e.g., building collaborative governance) and enhancing procedural justice (He 2016; Hu, Sun, and Chan 2013; Sun 2015). As the tension between local villagers and drillers intensifies, local opposition to shale gas drilling may become a more widespread social issue.

\section{Previous Literature}

NIMBY Syndrome

The "Not in my back yard" (NIMBY) reactions describe 
studies about NIMBY reactions into three perspectives: public irrationality, public selfishness, and public prudence. Public irrationality refers to zero tolerance of risk from local residents or unreasonable fear of risks. The psychometric framework has been characterized as empirical research supporting public irrationality, but the relevant empirical work provides little direct support for the perspective of public irrationality and does not provide strong evidences for the perspective of public irrationality as the primary explanation for opposition to a project siting (Kraft 2000; Kraft and Clary 1991; Dunlap and Olsen 1984; Slovic, Flynn, and Layman 1991). Public selfishness implies that local residents will oppose locally unwelcome facilities due to their self-interest (e.g., fear of reduced property values). The results from prior empirical work on this topic are mixed (Kunreuther and Easterling 1996; Kunreuther and Easterling 1990). Public prudence implies that the general public lacks information and familiarity with a technology. Providing more information and communication between specialists, policy makers and the general public will reduce public opposition to a technology. As appealing as this perspective may be, there is not a rich literature showing that communication reduces local opposition(Freudenburg and Pastor 1992). Overall, the possible explanations for local opposition are variable and the literature is mixed on what factors can change attitudes.

One limitation of the prior literature is that researchers may implicitly assume that there is only one motivation behind the local opposition. Yet it is possible that people are motivated to oppose an infrastructure siting proposal because of several major reasons, some involving selfishness, some involving conceptions of the public good (e.g., fairness or equity), and some rooted in insufficient information or knowledge.

Rather than focus on a single explanation, scholars have suggested a broader system-level approach that explores the social-psychological processes that shape local opposition (Aaen, 
Kerndrup, and Lyhne 2016; Freudenburg and Pastor 1992; Boholm and Lofstedt 2013). Our research contributes to this trend by studying the role of incentives in this broader framework. Incentives

Incentives can be regarded as a factor that shapes the general public's decision making process as well as a strategy that is implied by both the perspectives of public selfishness and public prudence. Incentives refer to making "payments" to those persons who are possibly negatively affected by a facility (Kunreuther and Easterling 1996; Been 1994; Liebe, Bartczak, and Meyerhoff 2017). The payments can take many forms including direct monetary payments or indirect forms of benefit, such as in-kind investments in schools, hospitals or other forms of infrastructure.

While we study incentives generally, compensation can be thought of as a specific form of incentive related to the magnitude of expected damages. Theoretically, compensation should be set at a level that can offset the expected negative impacts experienced by the residents. In practice, compensation design is more complicated and its effectiveness is varied. Compensation schemes have been criticized as morally unacceptable because security and health are inherent human rights that should not be traded off for material goods (Elster 1991; Cass, Walker, and Devine-Wright 2010). In this paper, incentives are not framed as compensation for actual negative impacts but as compensation for any potential negative impacts or inconvenience. Prior studies of the effectiveness of compensation on support for the siting of specific facilities draw mixed conclusions (Frey, Oberholzer-Gee, and Eichenberger 1996; Kunreuther and Easterling 1990; Dunlap and Baxter 1988; Hank and Kunreuther 1999). Scholars have found that the effectiveness of incentives depends on the type of proposed infrastructure (Kunreuther and Easterling 1996). Compensation can be effective for siting facilities such as solid waste 
landfills but do not work well for nuclear waste repositories because many residents feel that nuclear waste repositories will generate severe environmental and health risks (Kunreuther and Easterling 1996; Simon 1990; Portney 1991; Portney 1984, 2005). Scholars have also explored the role of moral considerations and the extent of the community's trust in government (Kunreuther, Linnerooth-Bayer, and Fitzgerald 1996; Frey, Oberholzer-Gee, and Eichenberger 1996; Jenkins, Maguire, and Morgan 2004).

Recent studies have found that some types of compensation are effective in increasing local support for shale gas development. For example, it has been found that incentives provided to the local community as a whole are often more effective in increasing local acceptance when compared to monetary incentives provided to individual households (García et al. 2016; Lo and Leung 2000). Paydar, Schenk, et al. (2016) found that incentives (especially reinvesting tax revenue from a shale gas project into local communities) significantly increase local acceptance for a hypothetical shale gas project while Paydar, Clark, et al. (2016) found a positive association between tax revenue allocation to local communities and local acceptance for shale gas development. With little in the Chinese context to substantiate these findings from the Western context, this research fills a gap in the literature.

In addition, some prior studies report only an association between local residents' attitudes and the types of compensation mentioned in a survey (Kunreuther and Easterling 1996; Kunreuther, Linnerooth-Bayer, and Fitzgerald 1996; Kunreuther, Slovic, and MacGregor 1996; García et al. 2016). Other scholars use the contingent valuation method to reveal willingness to pay (or willingness to accept) from the local public (Sun and Zhu 2014) or a choice experiment that provides different scenarios of a proposed facility and compensation (García et al. 2016). One problem with these methods is that factors that were not controlled by the research design 
might influence the extent of local opposition to the siting scenarios. The present research design minimizes the potential confounding effect from factors other than incentives/compensation. Similar to some prior experimental designs, we provided background information about a hypothetical shale gas development project to all respondents. We randomly assigned respondents into one of three groups (one control group only receiving background information and two treatment groups each receiving one of two types of incentive information beyond the background information). The random assignment allows us to rule out confounding factors as much as possible and estimate the pure effect of incentives.

Lastly, prior studies tend to focus on local opposition from the perspective of the facilities, or the psychological factors, and/or the moral dimensions (Frey, Oberholzer-Gee, and Eichenberger 1996; Kunreuther and Easterling 1996; García et al. 2016). Few studies explore the interaction effects of government-sponsored incentives/compensation and socio-demographic variables. Prior US public opinion studies on shale gas generally find that female and minority respondents are less likely to support shale gas development than older people, and that conservatives are more supportive of shale gas development than liberals. There are mixed or insignificant effects of education, income, and distance from the site (Boudet et al. 2014; Clarke et al. 2016; Davis and Fisk 2014). With respect to the Chinese context, age, distance, and level of income have significant effects on support for shale gas development in most cases (Wu et al. 2017; Yi et al. 2012; Guo and Ren 2017; He et al. 2014; Guo et al. 2015). Younger, less proximal, and higher income people are more likely to accept energy infrastructure in general. It is worth mentioning that the partisan factor, which is quite important in the American context, is not an issue in the Chinese context, where there is a single-party system. We expect that respondents of different ages, gender, levels of familiarity with shale gas, locations, and family 
structures could have different reactions to incentives for shale gas development, and we explore those potential interactions.

\section{Methods and Materials}

\section{Experimental design and hypothesis}

This paper assesses the impact of government-sponsored incentives on respondents' support for a hypothetical shale gas project in their community through a survey-embedded experiment. Previous studies have shown that experiments embedded within a large sample survey can produce results that balance suitably a researcher's interests in internal and external validity (Fehr et al. 2003; Schlueter and Schmidt 2010).

We randomly assigned respondents in each province to one control group (C) and two treatment groups (T1 and T2), respectively. Table 1 shows the distribution of respondents across groups in terms of major characteristics after randomization (gender, age, education, income, presence of children younger than 18 years old, perceiving living close to a shale gas site currently or not).

Respondents in the control group received only background information on the hypothetical shale gas project as shown below:

'Suppose that an energy company has determined that developing shale gas in your area is very promising. Several of the proposed sites are located within five kilometers from where you live. The gas production is expected to last for about 15 years.

The developers of the project have obtained exploration/exploitation licenses from the Ministry of Land and Resources (MLR) after strict evaluation of the compatibility of land zoning laws and a demonstration that the project, if carried out properly, will not damage the environment. 
Experience in other areas indicates that natural gas development could have both positive and negative impacts. Potential positive impacts can include job creation both in drilling and associated oil and gas industries and economic stimulus to the surrounding communities. Potential negative impacts can include use of large amounts of fresh water, an increase in truck traffic, damage to roads, decline in a community's quality of life, and potential damage to the environment. Experts estimate that shale gas development will directly affect a small percentage of households living within five kilometers from the drilling sites.'

To avoid any confounding effect from the order of the stated positive and negative impacts in the last paragraph, we randomized the order of those statements within each of the three groups.

The two treatments were: (T1) information about household compensation paid directly to impacted families was provided, and (T2) information about reinvesting shale resource tax revenue back in impacted communities for infrastructure construction or tax cuts was provided.

Respondents in the first treatment group (T1) received the first treatment after being presented the background information on the project. The exact wording of the first treatment is shown below:

'These impacted households will be compensated for the impacts of development. The standard compensation will be 10 percent of annual household income every year until the production ends. The compensation will come from local resource tax revenue from shale gas development that will be paid by energy companies.'

Respondents in the second treatment group (T2) received a combination of two treatments after being presented the background information. The exact wording is shown below:

'These impacted households will be compensated for the impacts of development. The standard compensation will be 10 percent of annual household income every year until the production ends. The compensation will come from local resource tax revenue from shale gas development that 
will be paid by the energy companies. In addition, $¥ 70$ million from the gas tax revenue will be used on local infrastructure projects and services in all impacted communities every year, including the construction or repair of roads and bridges, educational facilities, health care facilities, parks and recreation facilities, or tax cuts for residents. This extra local expenditure will largely improve local infrastructure projects and services.'

T1 helps only households in the community that are directly impacted by shale gas development. That would typically include only a small fraction of the residents of a village, town or municipality (often residents living quite close to drilling activity). T2 is framed as helping the community as a whole through infrastructure investment.

While we have used the word 'compensation' in this manuscript to describe the community reinvestment monies for infrastructure (T2), those funds are not tailored in any specific way to the extent of damage that was (or might be) experienced by the community. T2 is not described to respondents as a form of 'compensation' for damages; they are simply community investment funds of the specified magnitude for 'impacted communities'.

The first treatment condition - compensation of individually-impacted households for industrial development - is not prevalent policy but has occurred on an ad hoc basis in China. No official documents record the detailed standards or requirements for such compensation. Usually companies directly pay cash to residents who are living within a certain distance from the projects or companies transfer money to local governments to pay the individual residents (Ding 2017). When it comes to shale gas development, Shell once compensated villagers for land use and other inconveniences in Maoba, Sichuan. One person who lost one mu - a Chinese field measure equal to about 7,500 square feet - would likely receive at least $8400 \mathrm{RMB}(\$ 1,400)$ over two years in compensation. The payments were transferred to higher-level township 
governments that then distributed them to village-level leaders, in some cases as cash (Spegele and Scheck 2013). T1 tells us whether household compensation in China increases local acceptance compared to no compensation.

The second treatment condition adds community compensation to household compensation. Generally, revenues generated through taxes and fees on energy development are reinvested at the provincial level or in the more directly impacted communities. Since the Chinese government waived the natural resources tax and compensation fees for the shale gas industry in 2013, in order to increase the shale industry's profitability, the second treatment is not a current policy in China. T2 tells us whether adding community compensation to household compensation might provide additional local support. The addition of community compensation could be a policy choice in the future, if the Chinese government levies resource taxes and fees, as is standard policy in North America. Given sample size limitations (due to budgetary constraints), we did not add a separate arm of the experiment for community compensation alone. Adding community compensation to individual compensation was seen as a more policy-relevant issue than replacing individual compensation with community compensation (which is not seriously discussed in China).

After presenting the information, we asked respondents, given the information provided, whether they support or oppose the proposed shale gas development project in their area. The intensity of opinion was measured on a six-point scale (from strongly support to strongly oppose).

We expect stronger support for the hypothetical shale gas project from respondents in the two treatment groups, compared with those in the control group, if the incentives are effective. Specifically, we expect to see an individual incentive effect that is calculated by subtracting the average attitude of respondents in the control group from treatment group one (T1-C); and $a$ 
combination effect of individual and community incentives by subtracting the average attitude of respondents in the control group from the second treatment group (T2-C). Even though we did not implement a separate treatment group to test the effect of the community reinvestment effect by itself, assuming additivity, we still can derive the community reinvestment effect on public attitudes by subtracting the effects of the two treatments (T2-T1).

It is worth mentioning that before the treatment information was framed in the survey, we presented a narrative description and a visual representation of the process of shale gas extraction to respondents. The wording of the narrative employs neutral scientific language. Then we asked the respondents their general feeling about shale gas as a way to expand natural gas production in China on a six-point scale from strongly oppose to strongly support. Answers to this initial question may reflect general public attitudes toward shale gas development. By comparing this general attitude with the respondent's attitude after providing experimental information, we can infer whether there is a NIMBY-like reaction towards shale gas development in China.

Basic demographic variables such as age, gender, education level, income, and presence of children in the household were collected as part of the survey. We also asked the respondents whether they had ever heard or seen anything about shale gas before this survey (familiarity variable); and whether they perceive themselves living close to a shale gas development site now (the closeness variable).

\section{Survey administration}

The survey was first designed in English and then was translated into Chinese by one of the coauthors whose native language is Chinese. Next we asked another four PhD students who know both English and Chinese to compare the Chinese and English versions and suggest improvements in the Chinese version. The improved Chinese version was translated back to 
English and reviewed by another co-author of this paper. We then commissioned a professional survey company, Nuoda Consulting, Ltd. ("Nuoda"), to conduct a pretest of the survey by randomly selecting 30 respondents who live in the targeted area from its proprietary online panel, before administration of the final survey. We edited a couple of specific questions based on feedback from the pretest. Nuoda conducted the final survey from August $10^{\text {th }}$ to November $9^{\text {th }}$, 2016.

Online surveys have become popular in China due to the adoption of personal computers, easy access to the Internet, and the popularity of cell phones with Internet access capabilities. According to the China Internet Network Information Center (CINIC), more than 620 million people, about half of the total Chinese population, are so-called "netizens", which means citizens who have a tendency to surf the Internet very frequently. Among these 620 million netizens, 527 million use cell phones for Internet access (June 2014). In addition, online surveys can reduce the costs of survey administration substantially, thus providing access to a larger sample size with the same fixed cost compared with traditional face-to-face interviews or telephone surveys. The use of self-administration has other advantages such as removing the potential for interviewer effects that may influence attitude measures, allowing respondents flexibility in when they complete the survey, and providing respondents the opportunity to read the survey at their own pace, which may be particularly important for technical topics like energy. Thus, the online survey method has some significant advantages as well as the well-known limitations (e.g., excluding certain kinds of residents who are not Internet savvy).

\section{Survey sample}

The targeted area for the survey covers five provinces or autonomous regions in China - Sichuan, Chongqing, Hunan, Hubei and Guizhou. All selected provinces or autonomous regions have 
geological potential for shale gas development with various levels of development - from high development levels in Sichuan and Chongqing to virtually non-existent development levels in Hunan, Hubei and Guizhou. Certain prefectures and counties were oversampled (with 100 respondents from each prefecture or county) where hydraulic fracturing practices ("fracking") are currently used, so that we can have more variation in the data to investigate the location effects. These prefectures and counties are Weiyuan from Sichuan, Yibin from Sichuan, Fuling from Chongqing, and Yongchuan from Chongqing. The oversampling covered the most productive areas of shale gas development in China.

Nuoda recruited adult respondents 18 years of age or older based on our study requirements from their existing online panel 'yidiao wang'. Nuoda's online panel consists of more younger and highly educated people compared with the population census in the five Chinese provinces of interest. To make the sampling more representative, we required certain quotas in terms of education level and age distribution, thereby ensuring adequate numbers of less educated and older respondents. Since our primary interest is to explore a causal hypothesis through experimentation rather than to generate a representative statistic, we consider the disadvantages of the online panel to be less than the mentioned advantages. In order to guarantee high quality data, Nuoda has several protocols and standard practices regarding sample selection, online survey administration, and quality checking, and we also implemented several additional data checks prior to analysis.

A total of 6,316 eligible respondents were invited to enter the survey. The percent of invited eligible panel respondents who chose to participate was $25 \%$. After excluding respondents who had logically inconsistent responses, straight-lined answers, or completion times of less than a minimum of 7 minutes (average time to complete the survey was 20 minutes), 
there were 1,565 valid responses for analysis. Table 2 shows the key variables, and descriptive statistics for the variables in this analysis.

\section{Results}

In total, 91.6 percent of respondents support shale gas development as a way to expand natural gas production in China, though the intensity of support varies (13.0 percent strongly support, 27.6 percent moderately support, and 51.0 percent somewhat support). After presenting experimental information, 74.8 percent of respondents support the hypothetical shale gas project in their area (7.6 percent strongly support, 15.4 percent moderately support and 51.8 somewhat support). This comparison provides suggestive evidence that shale gas development can be regarded as a NIMBY facility because residents generally support shale gas development but they are more likely to oppose the activity when it is near their home.

Table 3 provides the distribution of the attitudes among the three experimental groups. The likelihood ratio test $(\mathrm{F}(10,15640)=3.30)$ implies that the treatment group assignment and the attitudes are not independent and group assignment is associated with respondents' opinions. We observe that $\mathrm{T} 1$ and $\mathrm{T} 2$ have a higher percentage of respondents who 'somewhat support' and 'moderately support' the project and a lower percentage of respondents who oppose the project compared to the control group. Those are the associations we expected prior to conducting the experiment.

By comparing the mean levels of support across the three groups, we obtain the treatment effects. Table 4 presents the results of the experiment. The average response of the control group is almost 4, indicating that the attitudes of the respondents in the control group are between 'somewhat oppose' and 'somewhat support'. The column labeled 'effect of T1' is the difference in the average response between $\mathrm{T} 1$ and $\mathrm{C}$, reflecting the average effect of the individual 
compensation; the column labeled 'effect of $\mathrm{T} 2$ ' is the difference of the average response between $\mathrm{T} 2$ and $\mathrm{C}$, indicating the average effect of a combination treatment.

Respondents who obtained information regarding household compensation and a combination of household compensation and community reinvestment are more likely to support the hypothetical shale gas project. The average treatment effect of household compensation is 0.19 points on the six-point scale and the average treatment effect of a combination of household compensation and community reinvestment is 0.20 . Both effects are statistically significant at the 0.01 level. The difference in the size of the treatment effect between $\mathrm{T} 1$ and $\mathrm{T} 2$ is not statistically significant, which means that adding community reinvestment does not significantly increase local residents' support for the shale gas project compared with the household compensation treatment.

Several reasons might explain these two interesting findings. One possible reason is that Chinese respondents have lower income compared with the countries studied in prior literature. Based on the compensation cycle introduced by Frey, Oberholzer-Gee, and Eichenberger (1996), monetary compensation can increase local acceptance insofar as people perceive an increase in expected lifetime income. The individual compensation is more likely to change Chinese people's expected income if their initial income/wealth position is not that high. Moreover, government-sponsored compensation efforts may be less common in Chinese culture than in Western democracies and thus they may seem more notable (favorable) to Chinese respondents when they are offered. Future research should explore this topic from economic, social, psychological and cultural perspectives.

We now explore the possibility that gender, age, education, income, family structure, familiarity and closeness might condition the relationship between compensation and attitudes 
toward the project. We split all respondents into subgroups. In Table $5^{1}$, we present the mean effects for each subgroup. We found statistically significant differences (at 0.01 level) in the effect of incentives on local residents' attitudes towards the hypothetical shale gas projects between age groups, education groups, income groups and current perceived distance to a shale gas development site. Older people are more likely to support the project after the individual compensation, but younger people are more likely to support the project after the combination compensation. Highly educated people are more likely to support the project after the compensation compared with less educated respondents. The mean score of high income respondents supporting the project is significantly increased due to the two treatments (T1 and T2). The medium income respondents support the project more frequently only after the addition of community reinvestment; the increased mean score of low income respondents supporting the project after the individual compensation is statistically significant. For respondents who perceive that they currently live close to a shale gas site, the individual compensation increases the mean score of support for the project. Yet for respondents who perceive that they currently don't live close to a shale gas site, the two treatments have similar effects.

The results for the socio-demographic variables should be viewed with more caution than the overall experimental effect because we are testing for multiple interactions with the two treatments. It seems likely that some interactions will show significant results, even without an underlying effect, since so many different interactions are explored. Since there is no hard theory underlying each of the tested interactions, the results here should be considered hypotheses for further study in different samples rather than established causal effects.

\footnotetext{
${ }^{1}$ We collapsed the income variation into three levels based on the population average of income level in the five provinces (2010 census) and the frequency distribution of the sample. Low income refers to annual household income of $30,000 \mathrm{RMB}$ or less (about $\$ 4,800$ or less) per year; medium income refers to annual household income between 30,001 to 200,000 RMB or less $(\$ 4,801$ to $\$ 30,000)$ per year; high income refers to annual household income of 200,001 RMB or more (above $\$ 30,000$ )
} 


\section{Conclusion and Discussion}

This study finds that individual compensation and a combination of individual compensation and community reinvestment can significantly increase local support for a hypothetical shale gas project. Compared with no compensation, the average effect of individual compensation is 0.19 points on a six-point scale; the average effect of the combination of individual compensation and community reinvestment is 0.20 points. The incremental effect of community reinvestment, while positive, is not statistically significant. The individual compensation effect and the combination effect are similar across family structure and familiarity, though the magnitudes are slightly different. Compensation effects are different across age, education level, perceived proximity to a site, and income. Compensation is more likely to increase support for the project if the respondents are highly educated, younger (for the combination of individual compensation and community reinvestment only), from a high income level and perceiving themselves living close to shale gas sites.

Our result is similar to García et al. (2016), who found individual compensation significantly increased local acceptance of a wind power farm. García et al. (2016) employed a choice experiment that provides two alternatives (private compensation and public compensation) and asks under which circumstances respondents will be willing to accept the wind farm. They found that willingness to accept construction of a wind farm is larger for private compensation than for public compensation. Our result is consistent with some Western surveys about the effect of compensation on the willingness to accept a moderately noxious facility (Kunreuther and Easterling 1996). On the other hand, our results are different from some previous case studies about the effect of compensation on local opposition to energy siting in the 1990s. In North American and European settings, most previous studies during this time did not find 
evidence that compensation reduces local opposition toward a radioactive waste repository or a nuclear power plant. Instead, some actually found the opposite effect of compensation (Gerrard 1994; Frey, Oberholzer-Gee, and Eichenberger 1996; Portney 1991).

Scholars have identified moral principles as a major reason why compensation fails to change the public's attitudes toward a given development. The monetary compensation is regarded as a bribe and therefore intensifies public opposition. This also explains prior findings that community compensation is more effective than individual monetary compensation in reducing local opposition. Community compensation may seem less immoral than monetary individual compensation. The other reason is the type of facility. Solid waste landfills and wind farms are presumably perceived to be less harmful than a radioactive waste repository. In the case of shale gas, future research should examine whether a shale gas facility is perceived as more or less risky than a facility with a known public aversion such as a nuclear power plant or radioactive waste repository.

Earlier research asked respondents whether they were willing to accept the construction of a NIMBY project using a yes-or-no question without compensation and then asked the same question again, to the same respondent, after the introduction of compensation (Frey, Oberholzer-Gee, and Eichenberger 1996; Jenkins-Smith et al. 1993; Bacot, Bowen, and Fitzgerald 1994). Many confounding factors might dilute the effect of compensation in this setting. Our experimental method with random assignment of samples into three groups avoids internal validity issues caused by confounding factors and avoids any perception by respondents that they are being manipulated with multiple offers.

In addition, this research sheds light on a new trend to study siting conflict. Rather than study who is opposing energy infrastructure siting, our study steps back and assumes that people 
might have multiple motivations (e.g. self-interest, need to know more information, and be more involved, etc.). Our research studies the effect of compensation in the process of making decisions about a siting proposal. More research is needed on what factors matter when people make such decisions. Future studies of siting conflicts and risk analysis can examine why specific factors influence people's decision making drawing from both qualitative and quantitative methods.

The results of our research could depend on the precise parameters in the experimental design. In our study, we set individual compensation at about $10 \%$ of annual household income and community reinvestment at about the average expenditure on infrastructure of a county-level government for all the five provinces.

From an economic perspective, the standard should be set to offset the expected negative impacts of shale gas development. Future research should evaluate the environmental and health impacts of shale gas development for the local residents carefully. Another criticism of paying compensation based on income is that this design is not fair to lower-income people. An alternative design would be to pay a unified amount of money to all impacted households, regardless of their income levels, though this approach might not be consistent with a formal economic model of damages.

There are other limitations in this research and opportunities for future research. First, the sample is an opt-in platform, bearing the possibilities of self-selection bias and creating concerns about external validity. Larger and more representative sampling techniques could buttress the literature in this area. Second, we did not test directly the effect of community reinvestment alone on local opposition. Future research could test the effect of different types of compensation in China, including the pure effect of community reinvestment. Third, results for community 
reinvestment may be sensitive to the type and magnitude of infrastructure to be subsidized. Alternative framings of the household compensation are also worth exploring, including more specific information on the share of nearby residents who are likely to receive compensation. Finally, incentives should be tested in a contested environment where opponents to shale gas frame the incentives as a bribe, similar to what has occurred in Western contexts.

(7982 words) 
References:

Aaen, Sara Bjørn, Søren Kerndrup, and Ivar Lyhne. 2016. "Beyond public acceptance of energy infrastructure: How citizens make sense and form reactions by enacting networks of entities in infrastructure development." Energy Policy 96 (Supplement C):576-86. doi: https://doi.org/10.1016/j.enpol.2016.06.031.

Alcorn, Jessica, John Rupp, and John D. Graham. 2017. "Attitudes Toward "Fracking": Perceived and Actual Geographic Proximity." Review of Policy Research 34 (4):504-36. doi: 10.1111/ropr.12234.

Bacot, Hunter, Terry Bowen, and Michael R. Fitzgerald. 1994. "Managing the solid waste crisis." Policy Studies Journal 22 (2):229-44.

Been, Vicki. 1994. "Locally Undesirable Land Uses in Minority Neighborhoods: Disproportionate Siting or Market Dynamics?" The Yale Law Journal 103 (6):1383-422. doi: 10.2307/797089.

Boholm, Asa, and Ragnar E. Lofstedt. 2013. Facility Siting:" Risk, Power and Identity in Land Use Planning": Routledge.

Boudet, Hilary, Christopher Clarke, Dylan Bugden, Edward Maibach, Connie Roser-Renouf, and Anthony Leiserowitz. 2014. "“Fracking" controversy and communication: Using national survey data to understand public perceptions of hydraulic fracturing." Energy Policy 65:57-67. doi: http://dx.doi.org/10.1016/j.enpol.2013.10.017.

Cass, Noel, Gordon Walker, and Patrick Devine-Wright. 2010. "Good Neighbours, Public Relations and Bribes: The Politics and Perceptions of Community Benefit Provision in Renewable Energy Development in the UK." Journal of Environmental Policy \& Planning 12 (3):255-75. doi: 10.1080/1523908X.2010.509558.

Clarke, Christopher E., Dylan Bugden, P. Sol Hart, Richard C. Stedman, Jeffrey B. Jacquet, Darrick T. N. Evensen, and Hilary S. Boudet. 2016. "How geographic distance and political ideology interact to influence public perception of unconventional oil/natural gas development." Energy Policy 97:301-9. doi: http://dx.doi.org/10.1016/j.enpol.2016.07.032.

Cvetkovich, T. T., and Ragnar E. Lofstedt. 1999. "Social trust: consolidation and future advances." Social trust and the management of risk. London: Earthscan Publications, Ltd:153-6.

Davis, Charles, and Jonathan M. Fisk. 2014. "Energy Abundance or Environmental Worries? Analyzing Public Support for Fracking in the United States." Review of Policy Research 31 (1):1-16. doi: 10.1111/ropr.12048.

Dear, Michael. 1992. "Understanding and overcoming the NIMBY syndrome." Journal of the American Planning Association 58 (3):288-300.

Ding, Wenlong, Yuxi Li, Meng Liu, Ruizhao Yang, Shujing Bao, Ning Dong, Xiaoqing Chen, et al. 2016. New Energy Strategy of China-A Collection of Publication of Shale Gas. Edited by Jinchuan Zhang: East China University of Science and Technology.

Ding, Wenqi. "Thousands Protest Chemical Plant Pollution in China's Hebei." http://www.rfa.org/english/news/china/hebei-pollution-05032017161045.html.

Duggan, Jennifer. 2013. "Kunming Pollution Protest is Tip of Rising Chinese Environmental Activism." 
Dunlap, Riley E, and Rodney K. Baxter. 1988. "Public Reaction to Siting a High- Level Nuclear Waste Repository at Hanford: A Survey of Local Area Residents." In.: the Social and Economic Sciences Research Center, Washington State University, Pullman, WA.

Dunlap, Riley E., and Marvin E. Olsen. 1984. "Hard-Path versus Soft-Path Advocates: A Study of Energ Activists." Policy Studies Journal 13 (2):413-28.

Elster, Jon. 1991. "Local justice: How institutions allocate scarce goods and necessary burdens." European Economic Review 35 (2):273-91. doi: https://doi.org/10.1016/00142921(91)90128-6.

Energy Information Administration. 2016. "Shale Gas Production Drives World Natural Gas Production."

Fehr, Ernst, Urs Fischbacher, Bernhard Von Rosenbladt, Jürgen Schupp, and Gert G Wagner. 2003. "A nation-wide laboratory: examining trust and trustworthiness by integrating behavioral experiments into representative survey."

Freudenburg, William R. 2004. "Can we learn from failure? Examining US experiences with nuclear repository siting." Journal of Risk Research 7 (2):153-69. doi: 10.1080/1366987042000171285.

Freudenburg, William R., and Susan K. Pastor. 1992. "NIMBYs and LULUs: Stalking the Syndromes." Journal of Social Issues 48 (4):39-61. doi: 10.1111/j.15404560.1992.tb01944.x.

Frey, Bruno S., Felix Oberholzer-Gee, and Reiner Eichenberger. 1996. "The Old Lady Visits Your Backyard: A Tale of Morals and Markets." Journal of Political Economy 104 (6):1297-313.

García, Jorge H., Todd L. Cherry, Steffen Kallbekken, and Asbjørn Torvanger. 2016. "Willingness to accept local wind energy development: Does the compensation mechanism matter?" Energy Policy 99 (Supplement C):165-73. doi: https://doi.org/10.1016/i.enpol.2016.09.046.

Gerrard, Michael. 1994. Whose backyard, whose risk: fear and fairness in toxic and nuclear waste siting. Cambridge, MA: The MIT Press.

Graham, John D., A. Mitchell, and John Rupp. 2013. "Risk Governance Guidelines for Unconventional Gas Development." In. Lausanne, Switzerland: International Risk Governance Council Report.

Graham, John D., John A. Rupp, and Olga Schenk. 2015. "Unconventional Gas Development in the USA: Exploring the Risk Perception Issues." Risk Analysis 35 (10):1770-88. doi: 10.1111/risa.12512.

Guo, Meiyu, Xi Lu, Chris P. Nielsen, Michael B. McElroy, Wenrui Shi, Yuntian Chen, and Yuan Xu. 2016. "Prospects for shale gas production in China: Implications for water demand." Renewable and Sustainable Energy Reviews 66:742-50. doi: http://dx.doi.org/10.1016/j.rser.2016.08.026.

Guo, Yue, and Tao Ren. 2017. "When it is unfamiliar to me: Local acceptance of planned nuclear power plants in China in the post-fukushima era." Energy Policy 100 (Supplement C):113-25. doi: https://doi.org/10.1016/j.enpol.2016.10.002.

Guo, Yue, Peng Ru, Jun Su, and Laura Diaz Anadon. 2015. "Not in my backyard, but not far away from me: Local acceptance of wind power in China." Energy 82:722-33. doi: http://dx.doi.org/10.1016/j.energy.2015.01.082. 
Hioe, Brian. 2016. "Anti-Nuclear Protests in China?".

$\mathrm{Hu}$, Desheng, and Shengqing Xu. 2013. "Opportunity, challenges and policy choices for China on the development of shale gas." Energy Policy 60 (Supplement C):21-6. doi: https://doi.org/10.1016/i.enpol.2013.04.068.

Hu, Y., Y. Sun, and RCK Chan. 2013. "Collaborative Governance In Nimby Facility Planning: Lessons From Site Selection Of Two Incineration Power Plants In Guangzhou." City Planning Review 37:16-9.

Hu, Yanlong, Weibin Huang, Jing Wang, Shijun Chen, and Jie Zhang. 2016. "Current status, challenges, and perspectives of Sichuan's renewable energy development in Southwest China." Renewable and Sustainable Energy Reviews 57:1373-85. doi: http://dx.doi.org/10.1016/j.rser.2015.12.138.

Jenkins, Robin R., Kelly B. Maguire, and Cynthia L. Morgan. 2004. "Host Community Compensation and Municipal Solid Waste Landfills." Land Economics 80 (4):513-28.

Jenkins-Smith, Hank, Howard Kunreuther, Richard Barke, and Doug Easterling. 1993. "UNM Mitigation/Compensation Survey." In. University of New Mexico, Albuquerquerque: Institute for Public Policy.

Kraft, Michael E, and Bruce B Clary. 1991. "Citizen participation and the NIMBY syndrome: Public response to radioactive waste disposal." Western political quarterly 44 (2):299328.

Kraft, Michael E. 2000. "Policy Design and the Acceptability of Environmental Risks: Nuclear Waste Disposal in Canada and the United States." Policy Studies Journal 28 (1):206-18. doi: 10.1111/j.1541-0072.2000.tb02024.x.

Kunreuther, Howard C., Joanne Linnerooth-Bayer, and K. B. Fitzgerald. 1996. "Siting hazardous facilities: Lessons from Europe and America."

Kunreuther, Howard, and Doug Easterling. 1996. "The Role of Compensation in Siting Hazardous Facilities." Journal of Policy Analysis and Management 15 (4):601-22.

Kunreuther, Howard, and Douglas Easterling. 1990. "Are Risk-Benefit Tradeoffs Possible in Siting Hazardous Facilities?" The American Economic Review 80 (2):252-6.

Kunreuther, Howard, Paul Slovic, and Donald MacGregor. 1996. "Risk Perception and Trust: Challenges for Facility Siting IIASA Symposium on Fairness and Siting." Risk: Health, Safety \& Environment 7:109-18.

Liebe, Ulf, Anna Bartczak, and Jürgen Meyerhoff. 2017. "A turbine is not only a turbine: The role of social context and fairness characteristics for the local acceptance of wind power." Energy Policy 107 (Supplement C):300-8. doi: https://doi.org/10.1016/j.enpol.2017.04.043. 
Liu, Pingli, Yinsheng Feng, Liqiang Zhao, Nianyin Li, and Zhifeng Luo. 2015. "Technical status and challenges of shale gas development in Sichuan Basin, China." Petroleum 1 (1):1-7. doi: https://doi.org/10.1016/i.petlm.2015.03.001.

Lo, Carlos Wing Hung, and Sai Wing Leung. 2000. "Environmental Agency and Public Opinion in Guangzhou: The Limits of a Popular Approach to Environmental Governance." The China Quarterly (163):677-704.

Luloff, Albert E., Stan L. Albrecht, and Lisa Bourke. 1998. "NIMBY and the hazardous and toxic waste siting dilemma: The need for concept clarification."

Luo, Yunjuan. 2014. "The Internet and agenda setting in China: The influence of online public opinion on media coverage and government policy." International Journal of Communication 8:24.

Ministry of Finance, and National Energy Administration. 2015. "Notice on releasing the subsidy policy for shale gas development and utilization." In.

Ministry of Land and Resources of the People's Republic of China. 2017. "Annual Statement of Oil and Gas Exploration and Drilling for 2016." In.

National Energy Administration. 2013. "First Shale Gas Industry Policy." In.

- - . 2016. "13th Five-Year Plan for Shale Gas (2016-2020)." In.

Paydar, Naveed H., Ashley Clark, John A. Rupp, and John D. Graham. 2016. "Fee disbursements and the local acceptance of unconventional gas development: Insights from Pennsylvania." Energy Research \& Social Science 20 (Supplement C):31-44. doi: https://doi.org/10.1016/j.erss.2016.04.007.

Paydar, Naveed, Olga Schenk, Ashley Bowers, Sanya Carley, John Rupp, and John D. Graham. 2016. "The effect of community reinvestment funds on local acceptance of unconventional gas development." Economics of Energy \& Environmental Policy 5 (1):131-56.

Pi, Guanglin, Xiucheng Dong, Cong Dong, Jie Guo, and Zhengwei Ma. 2015. "The Status, Obstacles and Policy Recommendations of Shale Gas Development in China." Sustainability 7 (3). doi: 10.3390/su7032353.

Portney, Kent E. 1984. "Allaying the NIMBY syndrome: The potential for compensation in hazardous waste treatment facility siting." Hazardous Waste 1 (3):411-21.

- - - 2005. "The Potential of the The Theory of Compensation for Mitigating Public Opposition to Hazardous Waste Treatment Facility Siting: Some Evidence from Five Massachusetts Communities." Policy Studies Journal 14 (1):81-9. doi: 10.1111/j.15410072.1985.tb00206.x.

Portney, Kent E. . 1991. Siting Hazardous Waste Treatment Facilities: The NIMBY Syndrome. New York: Auburn.

Rabe, Barry G. 1991. "Beyond the NIMBY Syndrome in Hazardous Waste Facility Siting: The Albertan Breakthrough and the Prospects For Cooperation in Canada and the United States." Governance 4 (2):184-206. doi: 10.1111/j.1468-0491.1991.tb00010.x.

Renn, Ortwin. 2008. Risk governance: coping with uncertainty in a complex world: Earthscan. Ruwitch, John, and David Stanway. 2012. "China Struggles for Solution to Growing NIMBY Movement." Reuters.

Schlueter, Elmar, and Peter Schmidt. 2010. "Special issue: Survey experiments." 
Slovic, Paul, James H. Flynn, and Mark Layman. 1991. "Perceived risk, trust, and the politics of nuclear waste." Science 254 (5038):1603-7.

Spegele, Brian. 2016. "Business news: China deepens natural-gas push---sinopect, others boost their efforts in shale, beijing subsidies back clean-energy sources." Wall Street Journal.

Spegele, Brian, and Justin Scheck. 2013. "Energy-Hungry China Struggles to Join Shale-Gas Revolution." The Wall Street Journal.

State Council of the People' Republic of China. 2014. "Energy Development Strategy Action Plan (2014-2020)." In.

Sun, Chuanwang, and Xiting Zhu. 2014. "Evaluating the public perceptions of nuclear power in China: Evidence from a contingent valuation survey." Energy Policy 69 (Supplement C):397-405. doi: https://doi.org/10.1016/i.enpol.2014.03.011.

Sun, Yi. 2015. "Facilitating generation of local knowledge using a collaborative initiator: $A$ NIMBY case in Guangzhou, China." Habitat International 46:130-7. doi: https://doi.org/10.1016/i.habitatint.2014.11.005.

Tian, Lei, Zhongmin Wang, Alan Krupnick, and Xiaoli Liu. 2014. "Stimulating shale gas development in China: A comparison with the US experience." Energy Policy 75 (Supplement C):109-16. doi: https://doi.org/10.1016/j.enpol.2014.07.025.

Wan, Zheng, Tao Huang, and Brian Craig. 2014. "Barriers to the development of China's shale gas industry." Journal of Cleaner Production 84 (Supplement C):818-23. doi: https://doi.org/10.1016/j.jclepro.2014.04.073.

Wu, Jing, I. Shin Chang, Qimanguli Yilihamu, and Yu Zhou. 2017. "Study on the practice of public participation in environmental impact assessment by environmental non-governmental organizations in China." Renewable and Sustainable Energy Reviews 74:186-200. doi: http://dx.doi.org/10.1016/i.rser.2017.01.178.

Yang, Guobin, and Craig Calhoun. 2007. "Media, Civil Society, and the Rise of a Green Public Sphere in China." China Information 21 (2):211-36. doi: 10.1177/0920203X07079644.

Yi, Zhiqiang, Quanfu Sun, Yekan Qian, Cuiping Lei, Junhua Xu, Zhongliang Ge, Yaoxian Zhao, Shunfei Yu, and Shouming Wu. 2012. "Public Awareness of Nuclear Power for Residents Living Close to Tanshan Nuclear Power Plants." China Public Health 9:1166-9.

Zhao, Xingang, and Yahui Yang. 2015. "The current situation of shale gas in Sichuan, China." Renewable and Sustainable Energy Reviews 50:653-64. doi: http://dx.doi.org/10.1016/j.rser.2015.05.023.

Zhong, Li-Jin, and Arthur P. J. Mol. 2008. "Participatory environmental governance in China: Public hearings on urban water tariff setting." Journal of Environmental Management 88 (4):899-913. doi: http://dx.doi.org/10.1016/j.jenvman.2007.04.018. 
Table 1. Characteristics of Each Group (proportion displayed in the cell)

\begin{tabular}{rlccc}
\hline Group & & Control & Treatment 1 & Treatment 2 \\
\hline Gender & Male & 0.62 & 0.63 & 0.62 \\
& Female & 0.38 & 0.37 & 0.38 \\
\hline Age & $18-35$ & 0.66 & 0.68 & 0.72 \\
& $36-60$ & 0.31 & 0.30 & 0.27 \\
& $>60$ & 0.03 & 0.02 & 0.01 \\
\hline Education & Less than college & 0.30 & 0.30 & 0.32 \\
& College or greater & 0.70 & 0.70 & 0.68 \\
\hline Household income & 30,000 RMB or less & 0.57 & 0.55 & 0.56 \\
& $30,001-200,000$ RMB & 0.38 & 0.39 & 0.40 \\
& $>200,000$ RMB & 0.05 & 0.06 & 0.04 \\
\hline Child under 18 & Yes & 0.50 & 0.47 & 0.46 \\
& No & 0.50 & 0.53 & 0.54 \\
\hline Perceived proximity & Close & 0.12 & 0.16 & 0.17 \\
& Not Close & 0.88 & 0.84 & 0.83 \\
\hline
\end{tabular}


Table 2. Variable Measurements and Descriptive Statistics

\begin{tabular}{|c|c|c|}
\hline Variable & $\begin{array}{l}\text { Description } \\
\end{array}$ & Descriptive Statistics \\
\hline Attitude & $\begin{array}{l}\text { Given this background information, would you support } \\
\text { or oppose the proposed shale gas development project } \\
\text { in your area? } \\
\text { 1-strongly oppose, 2-moderately oppose, 3-somewhat } \\
\text { oppose, 4-somewhat support, 5-moderately support, 6- } \\
\text { strongly support }\end{array}$ & $\mathrm{M}=3.96, \mathrm{SD}=1.01$ \\
\hline $\begin{array}{l}\text { Treatment } \\
\text { Groups }\end{array}$ & $\begin{array}{l}0=\text { control } \\
1=\text { treatment } 1 \\
2=\text { treatment } 2\end{array}$ & $\begin{array}{l}500 \text { control } \\
525 \mathrm{~T} 1 \\
546 \mathrm{~T} 2\end{array}$ \\
\hline$-\mathrm{C}$ & $\begin{array}{l}0=\text { treatment } 1 \text { or treatment } 2 \\
1=\text { control }\end{array}$ & $\begin{array}{l}1071 \mathrm{~T} 1 \text { or } \mathrm{T} 2 \\
500 \text { control }\end{array}$ \\
\hline$-\mathrm{T} 1$ & $\begin{array}{l}0=\text { control or treatment } 2 \\
1=\text { treatment } 1\end{array}$ & $\begin{array}{l}1046 \text { control or } \mathrm{T} 2 \\
525 \mathrm{~T} 1\end{array}$ \\
\hline$-\mathrm{T} 2$ & $\begin{array}{l}0=\text { control or treatment } 1 \\
1=\text { treatment } 2\end{array}$ & $\begin{array}{l}1025 \text { control or } \mathrm{T} 1 \\
546 \mathrm{~T} 2\end{array}$ \\
\hline Age & 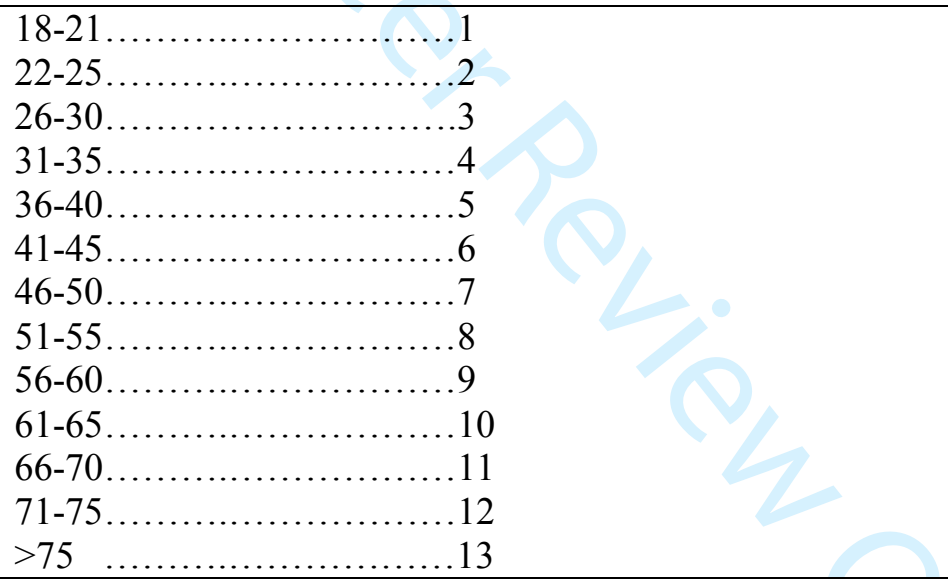 & $\mathrm{M}=3.90, \mathrm{SD}=2.32$ \\
\hline Female & $\begin{array}{l}1=\text { female } \\
0=\text { male }\end{array}$ & $\mathrm{M}=0.38, \mathrm{SD}=0.49$ \\
\hline Education & $\begin{array}{l}\text { No formal education } \\
\text { Primary School } \\
\text { Middle School } \\
\text { High School or equivalent } \\
\text { College or equivalent }\end{array}$ & $\mathrm{M}=5.16, \mathrm{SD}=1.24$ \\
\hline Income & $¥ 0-¥ 3000$ (1) $¥ 3001-¥ 7000$ & $\mathrm{M}=5.66, \mathrm{SD}=3.19$ \\
\hline
\end{tabular}




\begin{tabular}{|c|c|c|}
\hline & $\begin{array}{l}¥ 50001-¥ 80000 \\
¥ 80001-¥ 120000 \\
¥ 120001-¥ 200000 \\
¥ 200001-¥ 300000 \\
¥ 300001-¥ 1000000 \\
>1000000 \\
\text { (note: } 1 \$ \text { is approximately } 7 \mathrm{RMB})\end{array}$ & \\
\hline $\begin{array}{l}\text { Number of } \\
\text { children } \\
<18\end{array}$ & $\begin{array}{l}\text { How many children under the age of } 18 \\
\text { currently live with you at least } 6 \text { months out of } \\
\text { the year? }\end{array}$ & $\mathrm{M}=0.60, \mathrm{SD}=0.76$ \\
\hline Closeness & $\begin{array}{l}1=\text { perceived living close to a shale gas proj8 }(>\mathrm{qN} \text { :Nyql } \\
\mathrm{N} ¥ \mathrm{o} 0 \mathrm{Hy} 6 \mathrm{r}=7 \mathrm{~N} 8 \mathrm{~B} \$ \mathrm{~N} ¥(8 \$ \$: \mathrm{H} \square \square \mathrm{r} \square \$ \mathrm{BHy} 66=7>8 \$ \mathrm{BN} 8 \mathrm{E}\end{array}$ & $\begin{array}{l}\mathrm{J}: 8 \mathrm{~B} ¥>\text { HHy¥::HНy6e¥8HНy6 } \square \square ¥ 8 \mathrm{Pqy} \\
: \text { By6e=7(88\$B:HHy6n8\$By6u=7>8\$B:I }\end{array}$ \\
\hline
\end{tabular}


Table 3. Attitudes Toward the Hypothetical Shale Project Among Three Groups

\begin{tabular}{cccccccc}
\hline \multicolumn{7}{c}{ 6-scale point attitude toward the hypothetical project } \\
Group & $\begin{array}{c}\text { strongly } \\
\text { oppose }\end{array}$ & $\begin{array}{c}\text { moderately } \\
\text { oppose }\end{array}$ & $\begin{array}{c}\text { somewhat } \\
\text { oppose }\end{array}$ & $\begin{array}{c}\text { somewhat } \\
\text { support }\end{array}$ & $\begin{array}{c}\text { moderately } \\
\text { support }\end{array}$ & $\begin{array}{c}\text { strongly } \\
\text { support }\end{array}$ & Total \\
\hline Control & $1.09 \%$ & $1.73 \%$ & $7.28 \%$ & $15.59 \%$ & $3.83 \%$ & $2.36 \%$ & $31.88 \%$ \\
T1 & $0.89 \%$ & $1.28 \%$ & $5.94 \%$ & $16.61 \%$ & $5.30 \%$ & $3.32 \%$ & $33.35 \%$ \\
T2 & $0.56 \%$ & $0.83 \%$ & $5.56 \%$ & $19.62 \%$ & $6.26 \%$ & $1.92 \%$ & $34.76 \%$ \\
\hline & & & & & & & \\
Total & $2.56 \%$ & $3.83 \%$ & $18.79 \%$ & $51.82 \%$ & $15.40 \%$ & $7.60 \%$ & $100 \%$ \\
\hline
\end{tabular}

Note: $n=1565$; cell percentage; linearized standard error of cell percentage Pearson Chi-Square test: Chi2 $(10)=32.89, \mathrm{~F}(10,15640)=3.29, \mathrm{P}=0.0003$

Likelihood Ratio test: Chi2 $(10)=33.06, \mathrm{~F}(10,15640)=3.30, \mathrm{P}=0.0003$ 
Table 4. Treatment Effects of Compensation

\begin{tabular}{c|c|c|c}
\hline Group & Mean & Effect of T1 & Effect of T2 \\
\hline \multirow{2}{*}{ Control } & 3.83 & & \\
& $(0.05)$ & & \\
\cline { 2 - 4 } T1 & 4.02 & $0.19 * * *$ & \\
& $(0.05)$ & $(0.07)$ & \\
\cline { 2 - 4 } T2 & 4.03 & & $0.20 * * *$ \\
& $(0.04)$ & & $(0.06)$ \\
\hline
\end{tabular}

Note: $\mathrm{n}=1565 ; * * *$ at 0.01 significance level. 
Table 5. Mean Effects by Socio-Demographic Characteristics

\begin{tabular}{|c|c|c|c|c|c|c|}
\hline & $\mathbf{T 1}$ & $\mathbf{T 2}$ & $\mathbf{C}$ & $\begin{array}{c}\text { Individual } \\
\text { Effect }\end{array}$ & $\begin{array}{c}\text { Combination } \\
\text { Effect }\end{array}$ & $\begin{array}{c}\text { Community } \\
\text { Reinvestment } \\
\text { Effect } \\
\end{array}$ \\
\hline \multicolumn{7}{|l|}{ Gender } \\
\hline Female & 3.95 & 3.88 & 3.65 & 0.30 & 0.23 & -0.07 \\
\hline Male & 4.06 & 4.13 & 3.94 & 0.12 & 0.19 & 0.07 \\
\hline \multicolumn{7}{|l|}{$\operatorname{Age}^{* * *}$} \\
\hline Young $(<50)$ & 4.01 & 4.06 & 3.83 & 0.18 & 0.23 & 0.05 \\
\hline Old $(>=50)$ & 4.12 & 3.83 & 3.80 & 0.32 & 0.03 & -0.29 \\
\hline \multicolumn{7}{|l|}{ Education $* * *$} \\
\hline Less Educated (<college) & 3.96 & 4.01 & 3.86 & 0.10 & 0.15 & 0.05 \\
\hline More Educated (college or higher) & 4.05 & 4.04 & 3.82 & 0.23 & 0.22 & -0.01 \\
\hline \multicolumn{7}{|l|}{ Income*** } \\
\hline Low $(30,000$ RMB or less $)$ & 4.09 & 3.96 & 3.88 & 0.21 & 0.08 & -0.13 \\
\hline Medium (30,001-200,000 RMB) & 3.90 & 4.13 & 3.81 & 0.09 & 0.32 & 0.23 \\
\hline High $(>200,000 \mathrm{RMB})$ & 4.23 & 4.13 & 3.39 & 0.84 & 0.74 & -0.1 \\
\hline \multicolumn{7}{|l|}{ Children under 18} \\
\hline Child & 4.12 & 4.09 & 3.90 & 0.22 & 0.19 & -0.03 \\
\hline No Child & 3.92 & 3.97 & 3.76 & 0.16 & 0.21 & 0.05 \\
\hline \multicolumn{7}{|l|}{ Familiarity with Shale Gas } \\
\hline Familiar & 4.22 & 4.18 & 4.03 & 0.19 & 0.15 & -0.04 \\
\hline Not Familiar & 3.84 & 3.88 & 3.65 & 0.19 & 0.23 & 0.04 \\
\hline \multicolumn{7}{|l|}{ Perceived Proximity to Shale Gas Site ${ }^{* * *}$} \\
\hline Close & 4.43 & 4.19 & 4.07 & 0.36 & 0.12 & -0.24 \\
\hline Not Close & 3.95 & 4.00 & 3.80 & 0.15 & 0.20 & 0.05 \\
\hline
\end{tabular}

Note: $* * *$ The mean effects are statistically different across age, education, income and perceived proximity to shale gas sites at 0.01 significance level. 